\title{
The role of orographic barriers in the origin of extreme rainfalls as exemplified by the front of high Eastern Himalaya and the low northern slope of Carpathians
}

\author{
Elżbieta Cebulak', Piotr Gębica ๑ 2, Danuta Limanówka³, Leszek Starkel ${ }^{4}$, \\ Robert Pyrc ${ }^{5}$
}

${ }^{1}$ Former assistant in the Institute of Meteorology and Water Management - National Research Institute, Kraków Branch, Kraków, Poland

${ }^{2}$ University of Information Technology and Management in Rzeszów, Poland; piotrgebica@wp.pl

${ }^{3}$ Institute of Meteorology and Water Management - National Research Institute, Warszawa, Poland

${ }^{4}$ Institute of Geography and Spatial Organization, Polish Academy of Sciences, Kraków, Poland

${ }^{5}$ Institute of Meteorology and Water Management - National Research Institute, Kraków Branch, Kraków, Poland

\begin{abstract}
The paper discusses the role of orographic barriers in generating torrential precipitation in mountainous regions in different climatic zones, the Eastern Himalayas (tropical zone with well-developed monsoon activity) and the northern slope of the Carpathians (temperate zone with transitional climate). Attention has been paid to the different altitudes and courses of the orographic ridges as well as their location relative to the prevailing directions of influx of moist air masses. The cases analysed included torrential rains with monsoon circulation from the S-SW direction at the 2-3 km high edge of the Himalayas, with special consideration to the distance from the margin of the mountains and the exposure of the slopes. They generate frequent flood waves, landslides, debris flows and upbuilding of the alluvial cones in the foreland of the mountain barriers. The impact of the orographic barrier is significantly less marked in the Polish Carpathians. In the western part, the compact edge of the Western Beskids with an altitude of $0.5-1 \mathrm{~km}$ and the WSW-NEE course, exposed to moist air masses inflowing from the northern sector, is fragmented eastward into smaller mountain groups, which facilitates the penetration of moist masses of air with occurrence of prolonged precipitation into the mountains. At times, the storm cloud moves along the mountain edge (the margin of the Western Bieszczady Mts.). The marginal scarp of the Foothills has a northern exposure and a height of 150-200 m, and promotes frequent convective precipitation causing local flash floods in small streams. The cases of downpours and high discharges selected for the analysis were those for which there was available a dense network of measuring stations. An insufficient number of stations in constructing precipitation maps based on interpolation would lead to distorting the spatial image. If this were the case, then the role of slope exposure, which has an essential impact on the distribution of precipitation in mountainous regions, would be completely neglected.
\end{abstract}

Key words: heavy rainfalls, morphological barriers, floods, Himalayas, Carpathians

\section{Introduction}

The paper discusses the role of mountain barriers in generating extreme precipitation of diverse genetic types. These are either short storm downpours (with a duration of maximum 1-4 hrs), with high intensity reaching even several millimetres per minute, or continuous extreme rainfall events (lasting for 2-4 days) with intensity rates generally not exceeding 10-20 $\mathrm{mm} \mathrm{h}^{-1}$. A mountain range being an obstacle to the air masses causes their accumulation and a small impulse leads to the release of the moisture contained in them and formation of precipitation on the windward slope of the mountains. These phenomena are very common in high mountains (the Alps, the Himalayas) but they also occur in lower mountain ranges (Derbyshire 1976, Starkel 1976). 

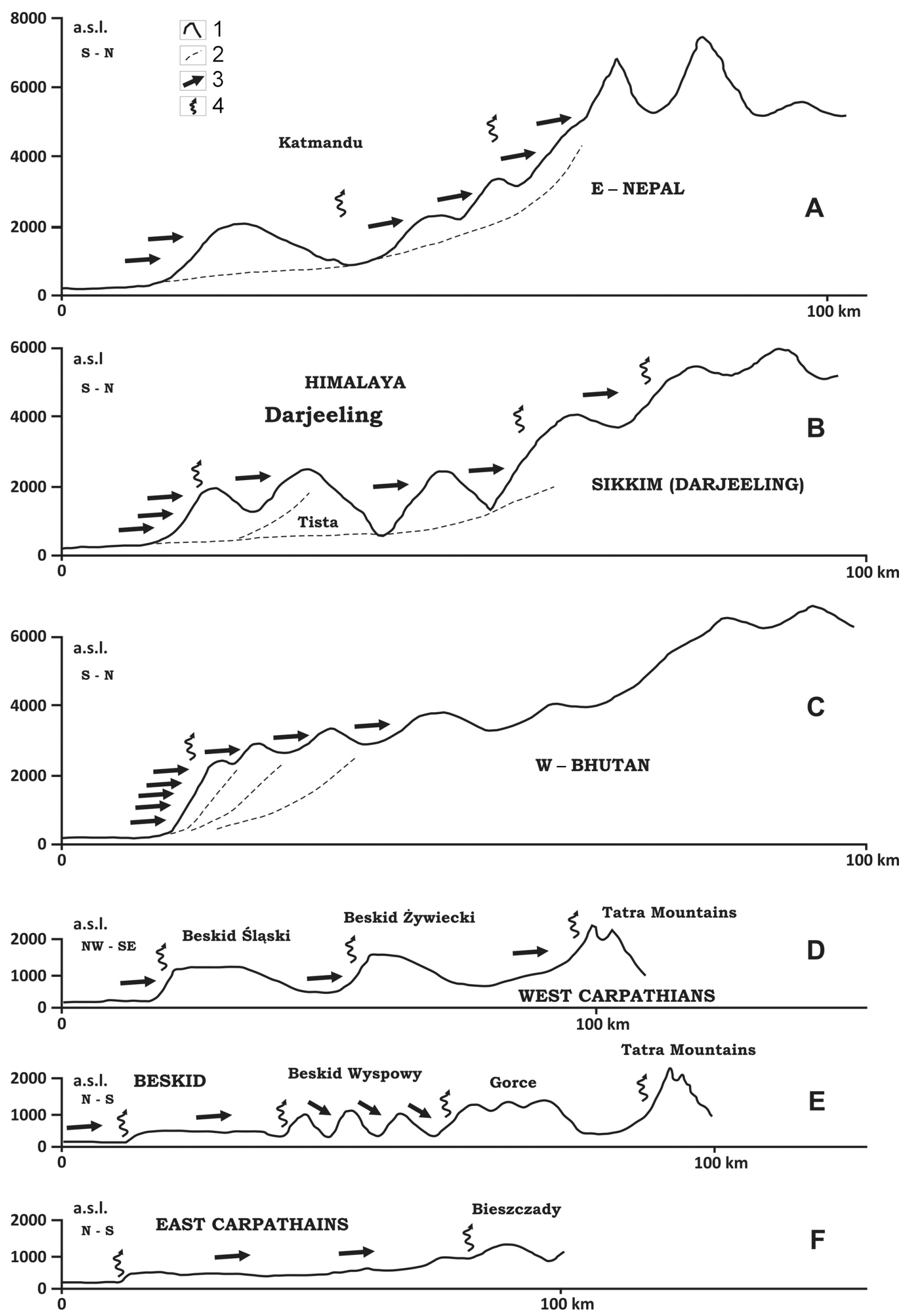

Fig. 1. Orographic barriers of the Himalayas (A-C) and the Carpathians (D-F) and the type of precipitation 1 - relief, 2 - river profile, 3 - heavy spreading rainfall, 4 - convectional rainfall 


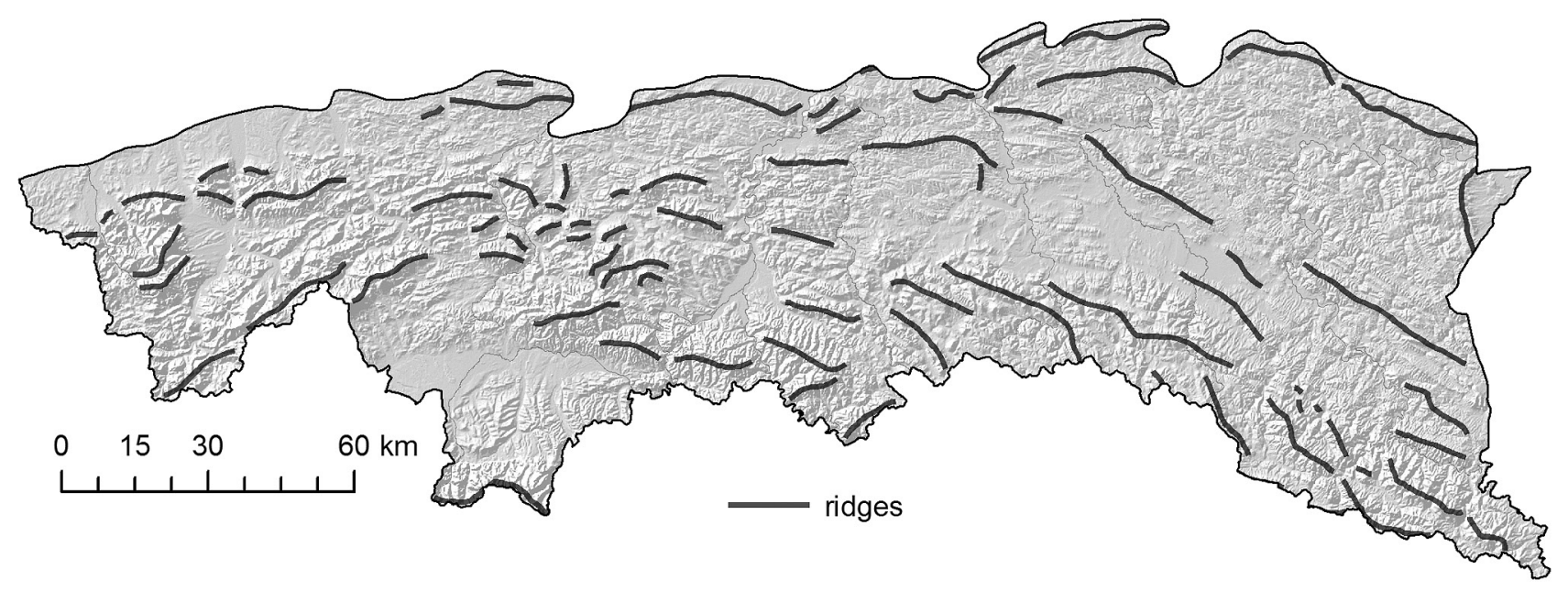

Fig. 2. Distribution of morphological ridges on the background of shaded digital elevation model in the Polish Carpathians

The examples discussed concern two orographic (mountain) barriers of different heights and contents, and of different location relative to the prevailing circulation of moist air masses, within which studies were carried out in the last decennia. One of them is the high and compact mountain barrier of the Himalayas, rising to $6,000-8,000 \mathrm{~m}$ a.s.l., reaching at the front of the mountain 2,000-3,000 $\mathrm{m}$ a.s.l., exposed to the cyclonic centres coming in from the south, from over the Indian Ocean (Fig. 1 A-C). It was studied in detail in the last decades in the section of the Sikkimese-Bhutanese Himalayas (Starkel 1972b, Froehlich, Starkel 1987, Starkel et al. 1998, Starkel, Basu 2000, Starkel et al. 2008). The other example discussed is the orographic barrier of the northern slope of the Carpathians with a parallel course, situated in a temperate climate zone. It rises with two or three morphological ridges of heights between $200 \mathrm{~m}$ and $1,000 \mathrm{~m}$ (with isolated ridges up to $2,500 \mathrm{~m}$ a.s.l.) (Starkel 1972a), exposed obliquely to the air masses coming predominantly from the north and north-west (Fig. 1 D-F, Fig. 2).

Heavy rainfalls cause formation of depressions moving from the Mediterranean Sea and northern Italy along the $\mathrm{Vb}$ track, according to Van Bebber's nomenclature (Degirmendžić, Kożuchowski 2016), north-eastwards, typically through Hungary and the Carpathians to southern Poland, Ukraine or Belarus. The low depressions from over Western Ukraine and Belarus bring warm, moist air masses also from over the Black Sea causing very heavy convective precipitation (Cebulak 1998, Cebulak et al. 2000).

The synergic effect of the orographic features of mountains (the height and content of the mountain ridges and their exposure to moist air masses) and the frontal processes causes occurrence of continuous rainfalls which usually cover the western part of the Carpathians reaching the Dunajec River valley and its tributary, the Biała Tarnowska (Biała) River. East of the Biała Tarnowska River valley, the highest daily rains can come from both prolonged rains and heavy rainfalls. Stormy, heavy or torrential rainfalls, of short duration and local, come from convection or are caused by the passing of fronts, mainly the cool front, and occlusion.

One of the objectives of the paper is to show that not only compact and high mountain massifs but also low orographic barriers that fulfil an important role in the distribution and intensity of precipitation generating flood waves. For the detailed analysis of precipitation events in the both mountain ranges, i.e. the Eastern Himalaya and the Carpathians, cases from regions with a dense measurement network were selected.

\section{Mountain ranges as barriers for moist air masses}

\section{Frontal barrier of the Eastern Himalaya}

In the Nepalese section, the Himalayan range is bipartite. The marginal ridges at an altitude below $1,500 \mathrm{~m}$ a.s.l. receives increased precipitation while the belt of intermountain basins is in a rain shadow (Fig. 1 A). Again, higher precipitation is recorded on the slope of the High Himalaya (Upreti, Dhital 1996). The precipitation map of Bhutan shows the highest values at the margin ridges of the mountains (annual precipitation (totals) over $5000 \mathrm{~mm}$ ), and proceeding further into the mountains as far as the Tibetan Plateau, rapidly decreasing precipitation volumes are observed (Baillie, Norbu 2004). The materials collected by the authors between these two regions, in the marginal part of the Sikkimese Himalayas and at the scarp of western Bhutan (Fig. 


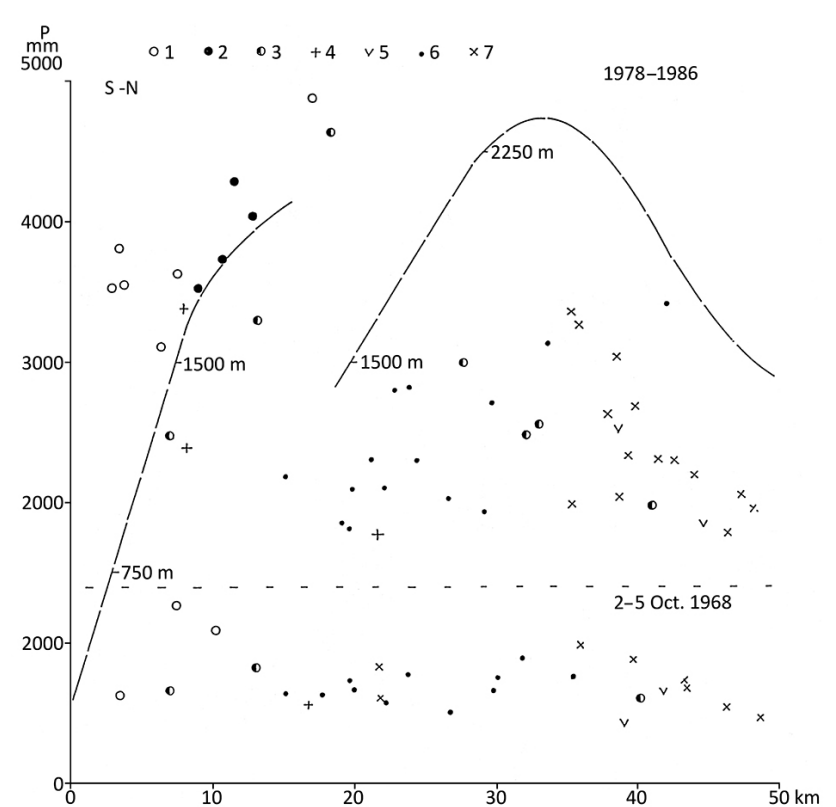

Fig. 3. Mean annual rainfall in 1978-1986 (vertical axis) and during continuous rain in October 1968 with the growing distance from the Himalaya front (horizontal axis: $0-50 \mathrm{~km}$ ). Broken line show frontal escarpment and higher ridge (altitude in $\mathrm{m}$ a.s.l.) (acc. Froehlich, Starkel 1987)

Location of stations: 1 - southern marginal slope, 2 - ridges on southern margin, 3 - other locations on ridges, 4 - northern slopes in southern margin, $5-\mathrm{W}$ - and E-exposed slopes, 6 southern exposed slopes in the interior, 7 - northern exposed slopes in the interior

1 B-C), provided detailed precipitation data, both annual and daily (Figs 3,4), due to the dense network of precipitation stations on tens of tea plantations, often at a distance of 3-4 km and located both on the southern and the northern slopes of the hills (Starkel 1972b, Starkel, Basu 2000, Starkel et al. 2008). During the cyclone attack on 2-5.10.1968, precipitation on the southern slope of the first (marginal) ridge exceeded $1000 \mathrm{~mm}$ and was lower by $50 \%$ on the opposite slope. On the next ridge, with southern exposure, precipitation reached over 900 $\mathrm{mm}$, and in the parallel valley of Great Rangitu, the rainfall was less than $500 \mathrm{~mm}$ (Fig. 3). In the last hours of the four-day-long rainfall, up to 200 $\mathrm{mm}$ precipitation fell, which triggered debris flows that transported boulders with a diameter of over $5 \mathrm{~m}$, while earth flows on tea plantations covered $20-30 \%$ of the slope areas (Starkel 1972b). The higher precipitation also continued further into the mountains, along the wide valley of the Tista River, cutting meridionally across the entire Sikkimese Himalayas. Precipitation of this type was recorded 3 times, in 1899, 1950 and 1968 (Starkel 1972b). An altogether different distribution was noted in the case of short heavy rainfalls, with precipitation rates up to $300-500 \mathrm{~mm}$ during 4 hours, which leaned

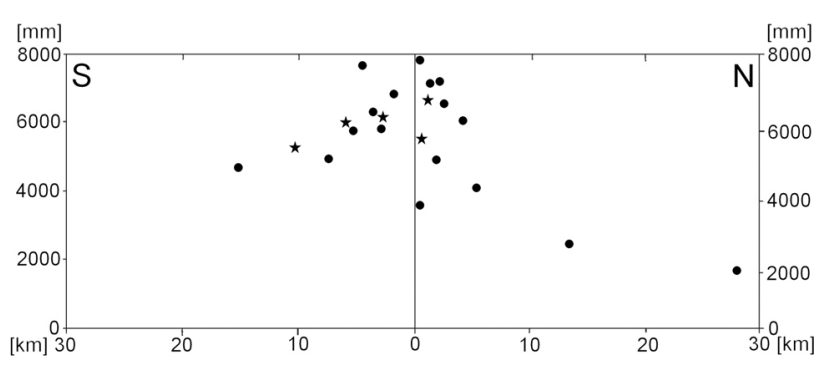

Fig. 4. Rainfall in 1998 at the margin of the Bhutanese Himalaya along $\mathrm{N}-\mathrm{S}$ transect from plain to mountains (acc. Starkel et al. 2008). Highest values of precipitation at the front of mountains; vertical line 0 indicates the margin of mountains; stations with stars are located on the line along the Torsa River showing a distinct decline of precipitation with growing distance from the front of mountains

against the first ridge in the region of Kurseong. Similar precipitation of $358 \mathrm{~mm}$ was produced by the 1998 heavy rainfall in Jungpana, which triggered debris flows (Starkel 2004).

In the western part of the Bhutanese Himalayas, at the margin of the mountains, rainfalls with a duration of 2-4 days and totals in the range of 800 $1000 \mathrm{~mm}$ were recorded on average every two years between 1990 and 2000. An exception was the year 1998, during which such rainfalls occurred twice (Starkel, Sarkar 2002, Soja, Starkel 2007). This frequency of rainfalls had an essential impact on the upbuilding of the mighty alluvial cones at the outlets of small valleys (with an area of between several and over a dozen $\mathrm{km}^{2}$ ), cutting the steep edge of the mountains. The plains of the alluvial fans also receive high precipitation. In 1998, the annual total rainfall at the distance of $10 \mathrm{~km}$ from the margin of the mountains decreased from approx. 7000 to approx. $5000 \mathrm{~mm}$ (Fig. 4), according to data from 4 stations situated along one line (at approx. $3 \mathrm{~km}$ intervals between the stations). The plains of the alluvial cones are built up due to water infiltration into the thick alluvia, and also cones often penetrate upwards into the mountain valleys (Starkel et al. 2008). With the absence of wide valleys like the Tista River valley, the decrease in the amount of precipitation is more and more significant farther into the Himalayas, and the annual total precipitation drops to $1000 \mathrm{~mm}$ (Baillie, Norbu 2004).

\section{The northern slope of the Carpathians; orography and types circulation of air masses}

Stretching along the length of $300 \mathrm{~km}$, the chain of the Polish (flysch) Outer Carpathians consists of several latitudinally running mountain ranges (the Beskids) and foothills in their foreland. In the western part, the mountain massif of the Beskids 
(the Silesian and Little Beskids), stretching SW$\mathrm{NE}$, enclosed by a denudation marginal ridge with a height of $500-800 \mathrm{~m}$, descends to the north with a narrow (5-15 km wide) platform of the Foothills (Starkel 1972a) (Fig. 1D, Fig. 2). At the distance of 20-30 km into the mountains, higher ridges of the Żywiecki Beskids with an altitude of 1,300-1,700 m a.s.l. occurred and at the distance of $60-70 \mathrm{~km}$ the high massif of the Tatra Mountains above 2,000 m a.s.l. In the Raba and Dunajec River basins, there stretches a zone of isolated ranges of island mountains with clearly marked ridges, reaching altitudes of 400-600 m, enclosed on the south by the higher range of the Gorce Mountains (up to 1,300 m a.s.l.) (Fig. 1E). The northern slopes of the Wyspowy (Island) Beskids merge into the Foothills zone with a width of $15-30 \mathrm{~km}$, enclosed by a marginal scarp with a height of 100-250 m. In the eastern part of the Carpathians (east of the Biała Tarnowska (Biała) River), there prevails a parallel arrangement of mountain ranges (ridges) stretching NW-SE and separated by depressions. In their foreland, there stretches a $35-70 \mathrm{~km}$ wide zone of the flat-topped Carpathian Foothills with an altitudes of 300 to $500 \mathrm{~m}$ a.s.l., dissected by $100-200 \mathrm{~m}$ valleys and intermountain basins (Starkel 1972a). The Foothills are enclosed on the north by a scarp (edge) with a height of 100-200 m and on the south they are bordered by a low ridge of the Low Beskids with altitudes of 700-900 m a.s.l., passing (merging) eastward into the ridges of the Bieszczady Mountains, the altitudes of which rise to between 700-900 m a.s.l. in the marginal (northern) part and $1350 \mathrm{~m}$ a.s.l. in the south-eastern part (Starkel 1972a) (Fig. $1 \mathrm{~F}, 2)$.

The formation of prolonged precipitation in the Carpathians is associated with the occurrence of stationary depressions, which is illustrated by examples from the years 1970, 1997 and 2010 (Fig. 5). Particularly high intensity of precipitation is attributed to the cyclones traversing from over the Mediterranean Sea and the Pannonian Basin north-eastwards (Niedźwiedź, Czekierda 1998). After crossing the chain of the Carpathians, such depressions remain for 2-3 days over Western Ukraine or south-eastern Poland. The orographic barrier of the mountains becomes an additional factor that enhances air circulation along the slope of the mountains, condensation of water vapour and formation of a thick layer of rain clouds. The stationary character of the depression ensures the constant delivery of moist air and intensive precipitation on the margin of the Western Beskids exposed towards the north, north west and north-east (Niedźwiedź, Czekierda 1998). Such was the origin of the majority of continuous rainfalls covering large areas and resulting in catastrophic floods.

\section{Examples of extreme rainfalls on the northern slope of Carpathians and their hydrogeomorphic effects}

\section{The downpours of 1970}

Between $17^{\text {th }}$ and $19^{\text {th }}$ July 1970 , after a relatively dry period, heavy rains occurred in southern Poland, bringing about a catastrophic flood in the upper Vistula basin (Fig. 5). The heaviest rainfall occurred on $18^{\text {th }}$ July, exceeding at many points $200 \mathrm{~mm}$ per day. In one day, on $18^{\text {th }}$ July 1970, 149 cases of $100 \mathrm{~mm}$ and higher precipitation events were recorded on the greater area of southern Poland (500 precipitation stations in the southern part of Poland). The daily amount of rain of this order was among the highest values noted in Poland in the last 100 years. It was only in the Tatra Mts., the Gorce Mts., the Wyspowy Beskids and the Beskid Sądecki that higher daily maxima occurred on 16 $6^{\text {th }}$ July 1934.

\section{The scarp of the Silesian Beskids and the Wyspowy (Island) Beskids in July 1997}

The heavy rainfalls that resulted in the catastrophic flood in the upper Vistula basin in July 1997 were also caused by the advection of the moisture-rich air from the northern sector, triggered by a stationary cyclone the centre of which remained on $4^{\text {th }}-9^{\text {th }}$ July 1997 over the Moravian Gate (Niedźwiedź, Czekierda 1998). The heaviest rainfall on $5^{\text {th }}-8^{\text {th }}$ July was centred over the western part of the Carpathians in the Silesian Beskids, the Zywiec Beskids and the Tatra Mts. (Fig. 5). On $6^{\text {th }}$ July, intense precipitation occurred in the Silesian Beskids on the windward slope of the mountains (Brenna $133 \mathrm{~mm}$ ) and on the Czech side, on the peak of the Lysá Hora, the daily rainfall was $234 \mathrm{~mm}$ (Kveton et al. 1997). On $8^{\text {th }}$ July, the orographic precipitation zone covered the Żywiecki Beskids and the Tatra Mountains, where precipitation exceeded $200 \mathrm{~mm}$ per day (Cebulak 1998).

On $9^{\text {th }}$ July, the depression began to move towards the east, and in the western part of the Carpathians, the rainfall began to decline as an effect of a high-pressure area from over Western Europe (Niedźwiedź, Czekierda 1998). In the afternoon on that same day, however, a large convection cell of storm clouds formed between the valleys of the Raba and the Dunajec Rivers, in the zone of the dissected scarp of the Wyspowy Beskids, which led to torrential rains of very high intensity in the eastern part of this area (of the order of $150 \mathrm{~mm}$ during 2 hours) (Cebulak 1998). The precipitation station at Rozdziele on the scarp of the Wyspowy Beskids recorded $120.2 \mathrm{~mm}$ of precipitation (Cebulak 1998) (Fig. 5). The effects of the downpour were cata- 

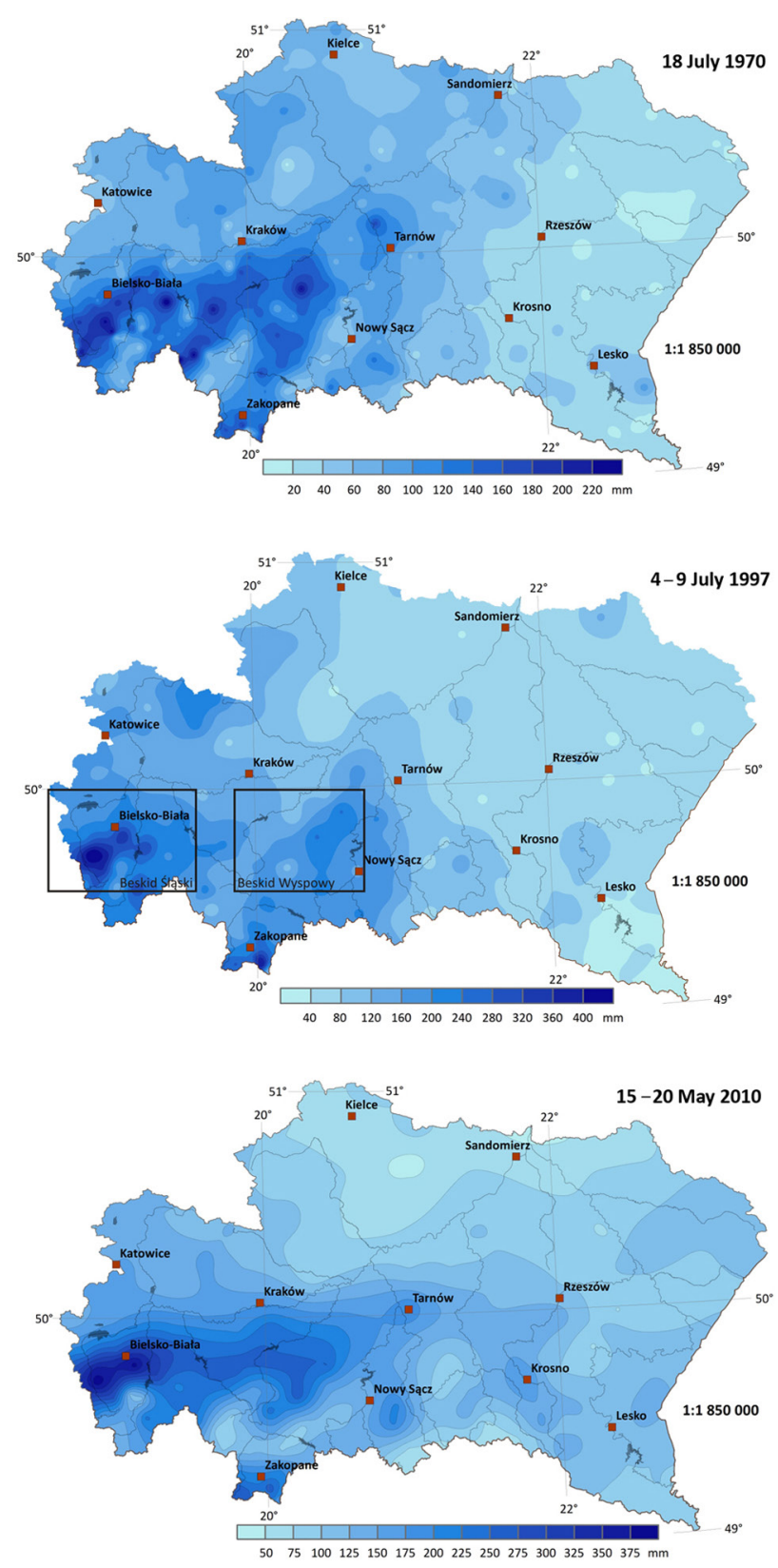

Fig. 5. Spatial distribution of precipitation on $18^{\text {th }}$ July 1970 , $4^{\text {th }}-9^{\text {th }}$ July 1997 and $15^{\text {th }}-20^{\text {th }}$ May 2010 in the Polish Carpathians (acc. Cebulak 1998)

strophic, because the precipitation affected the same regions where precipitation events of a continuous character had already occurred earlier and saturated the soils. The downpours caused a sudden rise in water level and the height of the flood wave in the channel of the Sanka River reached $5 \mathrm{~m}$. The greatest changes in relief occurred in the valley of the Uszwica River and the Sanka River, in the foreland of the Wyspowy (Island) Beskids (German 1997, Patkowski 2002). On the slopes, numerous landslides and mud and debris flows were triggered; and at the outlets of the valleys, alluvial cones with a thickness of 2-3 m occurred (German 1997, Rączkowski, Mrozek 2002, Gorczyca 2004). In the river channels, lateral erosion prevailed, at some points the channels were deepened by a few meters. Gravel bars deposited in the river channels with a maximum material fraction of $0.8-1.2 \mathrm{~m}$ and single blocks with diameters up to $2.5 \mathrm{~m}$ indicate that the sediment transport threshold characteristic for debris flows was exceeded at times. The settlements that suffered most were those at the margin of the mountains and in the valleys dissecting the edge of the mountains.

\section{The flood of 2010}

The precipitation events that caused the disastrous flooding began on 1st May 2010 and lasted for a whole month (Fig. 5). Monthly precipitation totals for May in the upper Vistula basin reached nearly $600 \mathrm{~mm}$ in the Western Beskids. The edge of the mountains with the highest concentration of rainfall is well marked. Particularly high precipitation total was reached in the Little Beskids where the highest amount of $593.5 \mathrm{~mm}$ was recorded at the Straconka station. Also, a rains exceeding $591 \mathrm{~mm}$ was recorded at the Ustron Równica station (a village in the Silesian Beskids). Over $500 \mathrm{~mm}$ of rainfall was also recorded in the Tatra Mountains where the highest monthly total of $522.6 \mathrm{~mm}$ occurred in the Valley of Five Polish Ponds (Dolina Pięciu Stawów).

The Bieszczady Mts. (July 2005 - the Upper San River)

Another example of the role of mountain scarps in directing storm rainfalls is the northern edge of the Western Bieszczady Mountains with a height of $300-500 \mathrm{~m}$, which forced, on $26^{\text {th }}$ July 2005 , the migration of a cumulonimbus cloud at its foot from the west towards the east in the course of several hours, which could be captured owing to several precipitation stations deployed along this route (Cebulak et al. 2008) (Figs 1F, 6). Precipitation lasting for $60-100$ minutes reached a maximum height of $131 \mathrm{~mm}$, and the maximum intensity was $2 \mathrm{~mm} \mathrm{~min}^{-1}$. After a few hours, the cloud crossed the ridges of the mountains. Detailed field observations of the hydrologic and geomorphologic effects immediately after this downpour made it possible to determine the southern limit of precipitation of the storm clouds that remained over the slope of the mountain range for a number of hours (Fig. 7).

\section{The scarp of the Carpathian Foothills (June 2009)}

The scarp of the Carpathian Foothills, with a height of 100-200 m, plays a significant role in the formation of intense storm precipitation of thermal origin and generation of local flash floods (Fig. 1E-F). Excep- 

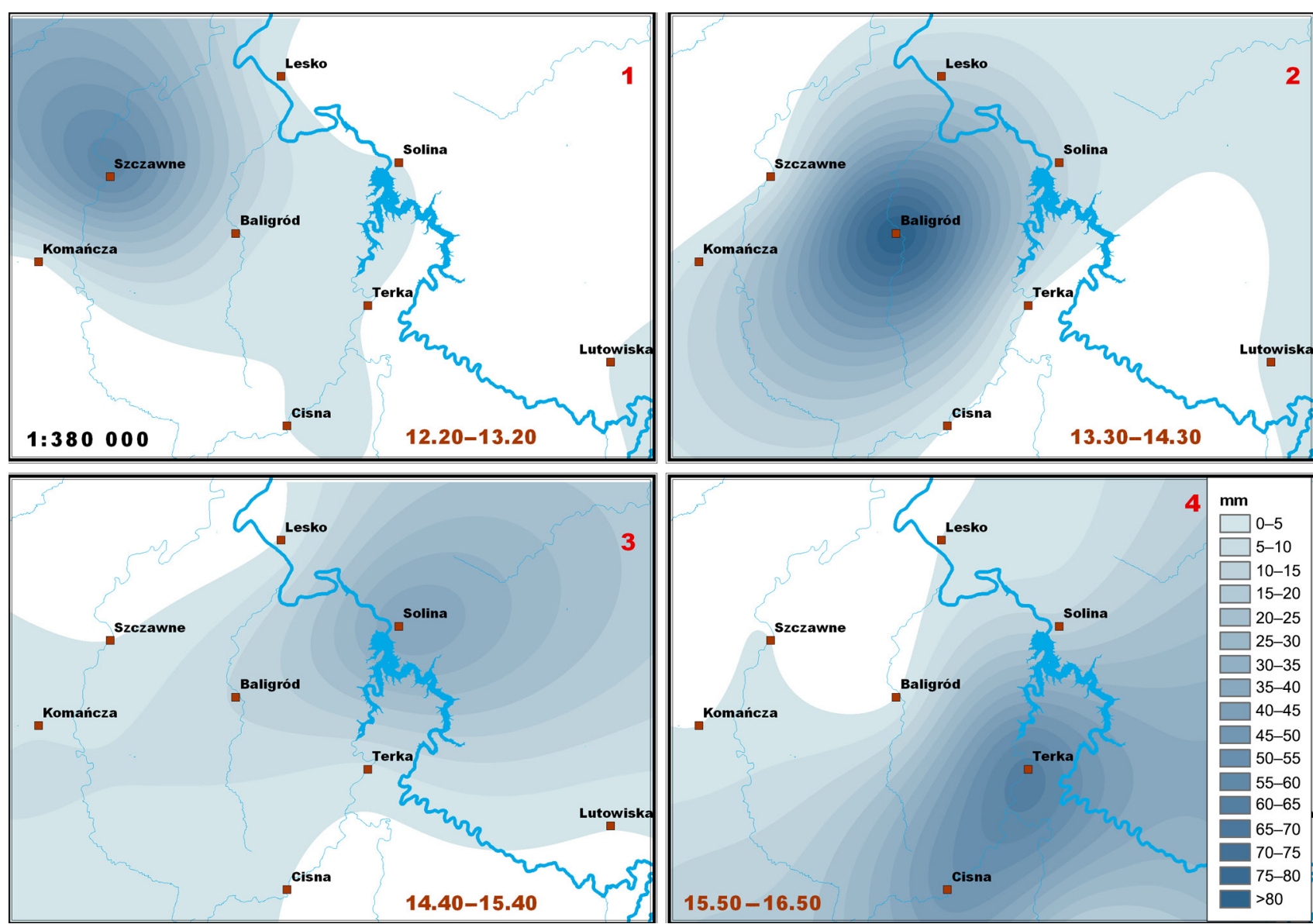

Fig. 6. Shift of rainfall area along the margin of the Bieszczady Mts. on $26^{\text {th }}$ July 2005 from hour to hour (acc. Cebulak et al. 2008)

tionally bountiful precipitation occurred at the scarp of the Foothills in June 2009. In the zone of a front moving from the SE in very warm and moist tropical air from over the Black Sea, storm cells formed and were enhanced by the occurrence of low morphological ridges on their way. The period of intense precipitation lasted from $19^{\text {th }}$ to $27^{\text {th }}$ June 2009 . The highest precipitation totals in that period exceeded $250 \mathrm{~mm}$ (Pilzno $271 \mathrm{~mm}$ and Brzeziny $248 \mathrm{~mm}$ ). Exceptionally intense precipitation was recorded on 23rd June in the Kańczuga village at the scarp of the Dynów Foothills; on $25^{\text {th }}$ June in the catchment of the Zawadka and the Wielopolka (Brzeźnica) Rivers at the scarp of the Strzyżów Foothills; and also on $26^{\text {th }}$ June in the catchment of the Wattok River at the scarp of the Ciężkowice Foothills.

On $25^{\text {th }}$ June, in the vicinity of the Zawada village at the scarp of the Strzyżów Foothills, storm cells formed and in the afternoon they merged into a multicellular storm structure causing formation of a downpour and a violent flash floods in the catchment of the Zawadka River with an area of approx. $20 \mathrm{~km}^{2}$, a length of $13.5 \mathrm{~km}$ and the Wielopolka (Brzeźnica) catchment (area of approx. $400 \mathrm{~km}^{2}$, length in the foothills $22 \mathrm{~km}$ ), a tributary of the Wisłoka (Fig. 8).
The highest precipitation on that day was recorded in Brzeziny village $(95.4 \mathrm{~mm})$ where the wave flood flowing down the scarp of the Foothills reached a height of almost $2 \mathrm{~m}$ above the floodplain. At the foot

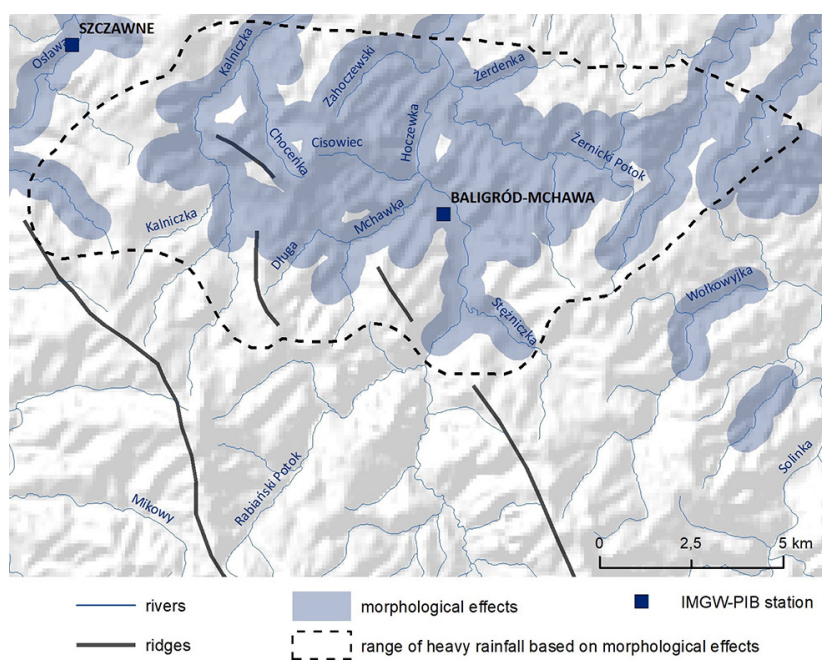

Fig. 7. Geomorphic effects - extend of extreme rainfalls registered after geomorphological effects of heavy downpour on $26^{\text {th }}$ July 2005 near Baligród in the Bieszczady Mts. (details see: Cebulak et al. 2008) 


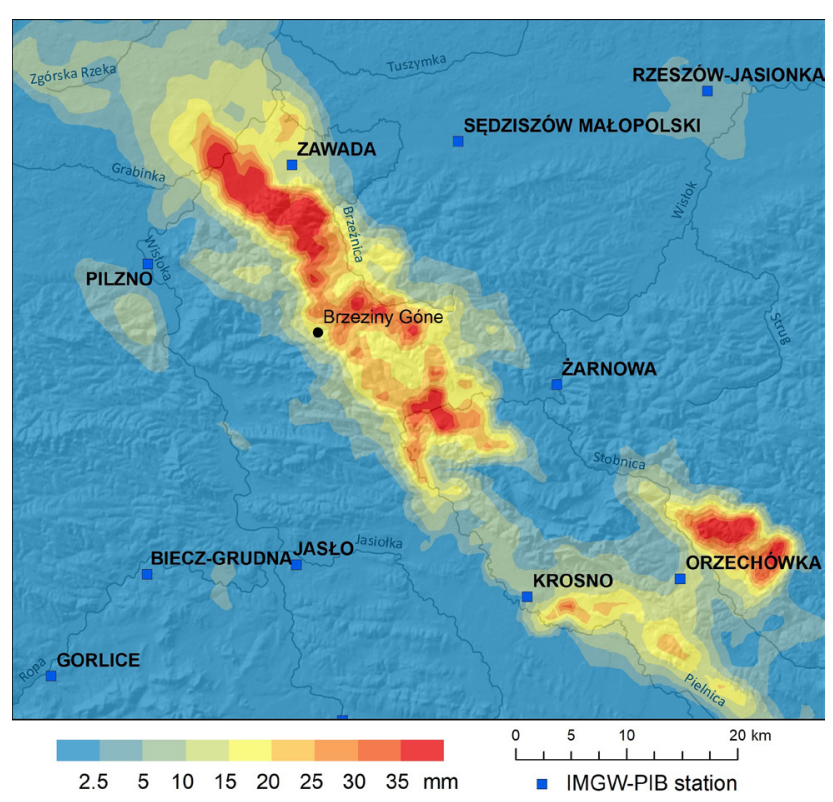

Fig. 8. Sum of precipitation in one hour during the downpour of $25^{\text {th }}$ June 2009 in the catchment of the Zawadka River and Wielopolka (Brzeźnica) River near Zawada village at the scarp of the Strzyżowskie Foothills; based on meteorological radar in Rzeszów

of the scarp, the Wielopolka River flooded the town of Ropczyce (Bryndal et al. 2010b). The considerable smaller stream Zawadka changed the course of its channel at the outlet from the Foothills and flooded a national road.

Torrential rain on $26^{\text {th }}$ June at the scarp of the Ciężkowice Foothills near Tarnów caused disastrous discharge in the catchment of the Wattok River, a

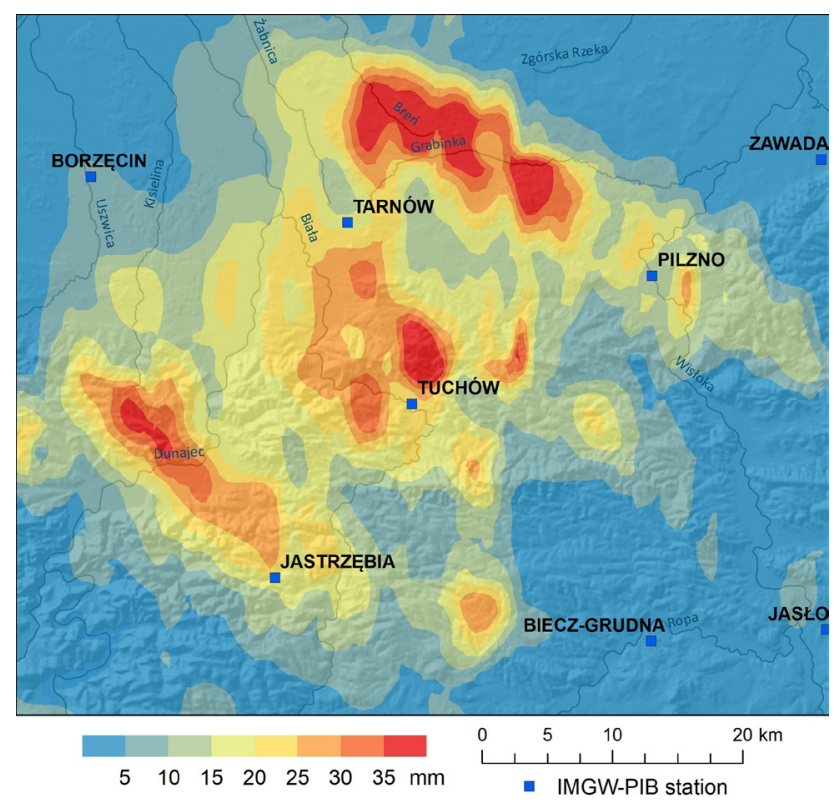

Fig. 9. Sum of precipitation in one hour during the downpour of $26^{\text {th }}$ June 2009 in the catchment of the Wątok River at the scarp of the Ciężkowickie Foothills near Tarnów; based on meteorological radar in Rzeszów tributary of the Biała Tarnowska (Biała) River (approx. area $91 \mathrm{~km}^{2}$, length in the foothills: $14 \mathrm{~km}$ ) (Fig. 9). The rainfall lasted approx. 4 hours, and the intensity of the precipitation reached $12 \mathrm{~mm}$ per 10 min (Bryndal et al. 2010a). In the catchment of the Watok stream covered by the intense precipitation, there are any precipitation stations; the daily rains at the nearest located stations were (26.06): at the station in Tarnów town, a distance of approx. $20 \mathrm{~km}$, $68.5 \mathrm{~mm}$ and at Pilzno $75.6 \mathrm{~mm}$. Based on radar data from the meteorological radars of the Institute of Meteorology and Water Management - National Research Institute, it can be concluded that the hourly precipitation locally exceeded $35 \mathrm{~mm}$ (Fig. 9). The flood wave formed as a result of the high discharge reached a height of between 0.6 and $1 \mathrm{~m}$ above the floodplain causing formation of numerous undercuts by erosion, with lengths of between 20 and $100 \mathrm{~m}$. Furthermore, activation of landslides was observed, as well as earthflows and forms of furrow erosion on cultivated fields (Bryndal et al. 2010a).

\section{Conclusions}

Orographic barriers, not only the high ones like the Himalayas but also the low ones like the scarp of the Carpathian Foothills, fulfil an essential role in generating and determining the frequency of extreme rainfalls, which is also reflected in their hydrogeomorphologic effects. These effects depend on the altitude of the morphological ridges, their content and orientation relative to the influx of the prevailing moist air masses. The examples from the Himalayas and the Carpathians described show how differentiated are both the conditions and effects, hydrologic and geomorphologic. An essential role is also played by the frequency of the events. A an example can serve the frequent high discharges in the 1990s, at the frontal ridges of the Himalayas (Starkel, Sarkar 2002) as well as the recurring high precipitation in the Carpathians in 1970, 1997-2001 and 2009-2010.

Selected for the analysis were those cases of downpours and high discharges for which there was available a dense network of measuring stations supported by a network of meteorological radars of the Institute of Meteorology and Water Management - National Research Institute, and where documentation was available concerning the effects of the intensity of precipitation marked in the natural environment. More and more often, radar data are used for direct analyses of the spatial distribution of rains as these do not lead to a distortion of the spatial image as opposed to the maps based on interpolation. By using radar data, it is possible to determine in an accurate manner the role of slopes (orographic ridges) in order 
to determine their effect on the distribution of precipitation in mountainous areas. Also the field mapping of geomorphological and hydrological effects of flash floods facilitate to determine the distribution and spatial extent of heavy precipitation.

\section{Acknowledgments}

The study was financed within the statutory research of the University of Information Technology and Management in Rzeszów and the Institute of Meteorology and Water Management - National Research Institute, Warszawa and Kraków Branch. We also thank two anonymous reviewers for all valuable comments.

\section{Author's contribution}

Elżbieta Cebulak: 10\%, Piotr Gębica: 20\%, Danuta Limanówka: 20\%, Leszek Starkel: 30\%, Robert Pyrc: 20\%.

\section{References}

Baillie I.C., Norbu C., 2004. Climate and other factors in the development of river and interfluve profiles in Bhutan, Eastern Himalayas. Journal of Asian Earth Sciences, 22: 539-553.

Bryndal T., Cabaj W., Gębica P., Kroczak R., Suligowski R., 2010a. Gwałtowne wezbrania spowodowane opadami deszczu w zlewni potoku Wątok (Pogórze Ciężkowickie). In: T. Ciupa, R. Suligowski (eds.), Woda w badaniach geograficznych. Instytut Geografii, Uniwersytet Jana Kochanowskiego w Kielcach: 315-327.

Bryndal T., Cabaj W., Suligowski R., 2010b. Hydrometeorologiczna interpretacja gwałtownych wezbrań małych cieków w źródłowej części Wielopolki w dniu 25 czerwca 2009 roku. In: A. Magnuszewski (ed.), Hydrologia w ochronie i kształtowaniu środowiska. Monografie Komitetu Inżynierii Środowiska PAN, 69, Warszawa: 81-91.

Cebulak E., 1998. Przegląd opadów ekstremalnych, które wywołały powodzie w XX wieku w dorzeczu górnej Wisły. In: L. Starkel, J. Grela (eds.), Powódź w dorzeczu górnej Wisły w lipcu 1997 roku. Konferencja naukowa w Krakowie, 7-9 maja 1998: 21-37.

Cebulak E., Faško P., Lapin M., Štastný P., 2000. Extreme precipitation in the Western Carpathians. In: B. Obrębska-Starkel (ed.), Images of Weather and Climate. Prace Geograficzne Instytutu Geografii Uniwersytetu Jagiellońskiego, 108, Kraków: 117-124.

Cebulak E., Limanówka D., Malota A., Niedbała J., Pyrc R., Starkel L., 2008. Przebieg i skutki ulewy w dorzeczu górnego Sanu w dniu 26 lipca 2005 roku. Materiały Badawcze 40, seria: Meteorologia, Instytut Meteorologii i Gospodarki Wodnej, Warszawa: $1-56$.

Cebulak E., Niedźwiedź T., 1998. Ekstremalne zjawiska opadowe w dorzeczu górnej Wisły w latach 1995-1996. In: L. Starkel (ed.), Geomorfologiczny i sedymentologiczny zapis lokalnych ulew. Dokumentacja Geograficzna 11, Instytut Geografii i Przestrzennego Zagospodarowania PAN, Wrocław: 1-107.

Degirmendžić J., Kożuchowski K.M., 2016. Aktywność niżów śródziemnomorskich nad Polską a cyrkulacja w górnej i środkowej troposferze (Activity of Mediterranean lows over Poland versus upper and middle tropospheric circulation). Przegląd Geofizyczny LXI(1-2): 3-30.

Derbyshire E., ed., 1976. Geomorphology and Climate, J. Wiley, London.

Froehlich W., Starkel L., 1987. Normal and extreme monsoon rains - their role in the shaping of the Darjeeling Himalaya. Studia Geomorphologica Carpatho-Balcanica, 21: 129-160.

German K., 1997. Przebieg wezbrania powodzi 9 lipca 1997 roku w okolicach Żegociny oraz ich skutki w krajobrazie. In: L. Starkel, J. Grela (eds.), Powódź w dorzeczu górnej Wisły w lipcu 1997 roku. Konferencja naukowa w Krakowie, 7-9 maja 1998: 177-184.

Gorczyca E., 2004. Przekształcanie stoków fliszowych przez procesy masowe podczas katastrofalnych opadów (dorzecze Łososiny). Wyd. Uniwersytetu Jagiellońskiego, Kraków: 1-101.

Kveton V., Smensky R., Vesely R., 1997. Rozlozeni srazek pri povodnich v červenci 1997, Meteorologicke Zpravy 50, 6: 172-177.

Niedźwiedź T., Czekierda D., 1998. Cyrkulacyjne uwarunkowania katastrofalnej powodzi w lipcu 1997 roku. In: L. Starkel, J. Grela (eds.), Powódź w dorzeczu górnej Wisły w lipcu 1997 roku. Konferencja naukowa w Krakowie, 7-9 maja 1998: 53-66.

Patkowski B., 2002. Rola ekstremalnych wezbrań w kształtowaniu koryta Uszwicy (na przykładzie powodzi w latach 1997-1998), Prace Instytutu Geografii Akademii Świętokrzyskiej, Kielce: $139-152$.

Rączkowski W., Mrozek T., 2002. Activity of landsliding in the Polish Flysch Carpathians at the end of 20th century. Studia Geomorphologica Carpatho-Balcanica, 36: 91-101.

Soja R., Starkel L., 2007. Extreme rainfalls in Eastern Himalaya and southern slope of Meghalaya Plateau and their geomorphological impacts. Geomorphology, 84: 170-180.

Starkel L., 1972a. Charakterystka rzeźby Polskich Karpat i jej znaczenie dla gospodarki ludzkiej. Problem Zagospodarowania Ziem Górskich, 10: 75-150.

Starkel L., 1972b. The role of catastrophic rainfalls in the shaping of the relief of Lower Himalaya (Darjeeling Hills). Geographia Polonica, 21: 103-147.

Starkel L., 1976. The role of extreme (catastrophic) meteorological events in contemporary evolution of slopes. In: Derbyshire E. (ed.) Geomorphology and climate, J. Wiley, Chichester: 203246.

Starkel L., 2004. Temporal clustering of extreme rainfall events in relief transformation. Journal Geological Society of India 64, 4: 517-523.

Starkel L., Basu S. (ed.), 2000. Rains, Landslides and Floods in the Darjeeling Himalaya. Indian National Science Academy, New Delhi: 1-168.

Starkel L., Sarkar S., 2002. Different frequency of treshold rainfalls transforming the margin of Sikkimese and Bhutanese Himalaya. Studia Geomorphologica Carpatho-Balcanica, 36: 51-67.

Starkel L., Sarkar S., Soja R., Prokop P., 2008. Present-day evolution of Sikkimese-Bhutanese Himalayan piedmont. Prace Geograficzne, 219, Instytut Geografii i Przestrzennego Zagospodarowania PAN: 1-122.

Upreti B.N., Dhital M.R. 1996. Landslides studies and management in Nepal. ICIMOD, Kathmandu: 32-38. 